\title{
Monetary Value of Youth towards Marriage
}

\author{
Y. D. Haritha* and Uma Devi \\ Department of Human Development and Family Studies, College of Home Science, Acharya \\ N. G. Ranga Agricultural University, India \\ *Corresponding author
}

\section{A B S T R A C T}

Keywords

Monetary value, Youth, Marriage

Article Info

\section{Accepted:}

12 April 2021

Available Online:

10 May 2021
The present study makes an attempt to understand the Monetary value of youth towards marriage. The results revealed that marriage fulfils various needs of individuals. Fulfilling the needs depends upon the monetary or economic resource that each partner brings in marriage. One of the strong feelings expressed are their duty to support their husband economically. The results revealed that 92 percent expressed in selecting the marriage partner economic status of the family must be counted, 83 percent expressed family finance should be left to a wife to have economic independence, 98 percent expressed in present days it is also a duty of wife to support her husband economically.

\section{Introduction}

The path to a stable family life has become longer in recent decades. Monetary or Economics seem likely to be a key factor affecting young adults' relationship quality. Several studies have linked financial instability to relationship dissolution and divorce (Burstein, 2007; Hoffman \& Duncan, 1995; Kalmijn, Loeve, \& Manting, 2007; Lewin, 2005; South, 2001). Explanations for this relationship suggest that economic hardship may place stress on couples, thereby increasing conflict and leading eventually to divorce (Ono, 1998; White \& Rogers, 2000). Understanding how and under what circumstances economic factors affect perceived relationship quality will contribute greatly to an understanding of the sources of stability and stress for young couples.

\section{Materials and Methods}

It focused on youth (15 to 29 years). The main focus of the study was to study monetary value of youth towards marriage.

\section{Results and Discussion}

The data collected with respect to understand the Monetary value of youth towards marriage. 
Table.1

\begin{tabular}{|c|c|c|c|c|}
\hline \multirow{3}{*}{ S.no } & \multirow{3}{*}{ Statements } & \multicolumn{3}{|c|}{$(n=60)$} \\
\hline & & \multicolumn{3}{|c|}{ Total } \\
\hline & & Category & $\mathbf{F}$ & $\mathbf{P}$ \\
\hline \multirow[t]{2}{*}{$\mathbf{1}$} & \multirow{2}{*}{$\begin{array}{l}\text { In selecting the marriage partner economic status of } \\
\text { the family must be counted }\end{array}$} & Yes & 55 & 92 \\
\hline & & No & 5 & 8 \\
\hline \multirow[t]{2}{*}{2} & \multirow{2}{*}{$\begin{array}{l}\text { Family finance should be left to a wife to have } \\
\text { economic independence }\end{array}$} & Yes & 50 & 83 \\
\hline & & No & 10 & 17 \\
\hline \multirow[t]{3}{*}{3} & \multirow{2}{*}{$\begin{array}{l}\text { In present days it is also a duty of wife to support } \\
\text { her husband economically }\end{array}$} & Yes & 59 & 98 \\
\hline & & No & 1 & 2 \\
\hline & & Total & 60 & 100 \\
\hline
\end{tabular}

The results revealed that 92 percent expressed in selecting the marriage partner Economic status of the family must be counted, 83 percent expressed family finance should be left to a wife to have economic independence, 98 percent expressed in present days it is also a duty of wife to support her husband economically.

The data collected with respect to understand the Monetary value of youth towards marriage. The results revealed that marriage fulfils various needs of individuals. Fulfilling the needs depends upon the monetary or economic resource that each partner brings in marriage. One of the strong feelings expressed are their duty to support their husband economically.

\section{References}

Burstein N R. Economic influences on marriage and divorce. Journal of Policy Analysis and Management. 2007; 26:387-429.
Hoffman S D, Duncan G J. The effect of incomes, wages, and AFDC benefits on marital disruption. Journal of Human Resources. 1995;30:19-41.

Kalmijn M, Loeve A, Manting D. Income dynamics in couples and the dissolution of marriage and cohabitation. Demography. 2007; 44:159-179.

Lewin A C. The effect of economic stability on family stability among welfare recipients. Evaluation Review. 2005; 29:223-240.

Ono H. Husbands' and wives' resources and marital dissolution. Journal of Marriage and the Family. 1998; 60:674-689.

South S J. Time-dependent effects of wives' employment on marital dissolution. American Sociological Review. 2001;66:226-245

White L, Rogers S J. Economic circumstances and family outcomes: A review of the 1990s. Journal of Marriage and Family. 2000; 62:1035-1051.

\section{How to cite this article:}

Haritha, Y. D. and Uma Devi. 2021. Monetary Value of Youth towards Marriage. Int.J.Curr.Microbiol.App.Sci. 10(05): 15-16. doi: https://doi.org/10.20546/ijcmas.2021.1005.003 